\title{
Anaesthetic management of a parturient with prior myocardial infarction and coronary artery bypass graft
}

\begin{abstract}
An increasing number of parturients suffering from ischaemic heart disease require anaesthetic care for labour and vaginal delivery. We present the case of a 42-year-old gravida who had previously suffered a myocardial infarction and undergonc coronary artery bypass grafting. Management was directed toward prevention of haemodynamic instability by alleviation of pain and stress while minimizing the risk of anaesthesic complications. Monitoring incituded a central venous catheter, pulse oximetry, and an automated blood pressure cuff. A judiciously administered segmental lumbar extradural block was instituted early, utilizing lacal andestherics with the narcotic fentanyl.
\end{abstract}

Coronary artery disease and myocardial infarction are uncommon entities in women of childbearing age. Ginz ${ }^{1}$ quoted an incidence of myocardial infarction in 1:10,000 pregnancies. Rarer still is the parturient who has recovered from a myocardial infarct and subsequent revascularization procedure. We are describing the successful anaesthetic management of a woman who delivered vaginally three years after an infarct and coronary artery bypass.

\section{Case report}

A 42-year-old secundigravida was admitted to our psychiatric service at 37 weeks' gestation for an episode of paranoid schizophrenia. Her prenatal care took place at an outlying hospital where she had delivered her first child vaginally 12 years earlier. Three years prior to this

\section{Key words}

ANAESTHESIA: obstetric; HEART: myocardial infarction, coronary artery bypass graft.

From the Department of Anesthesiology $J 1226$ Albert Einstein College of Medicine, 1300 Morris Park Ayenue, Bronx,

New York 10461.

Address correspondence to: Dr. Marx. admission she had suffered an anterior wall myocardial infarct at which time familial hypercholesterolaemia was diagnosed. She then underwent triple-vessel coronary artery bypass grafting. After an uneventful recowery, a radionuclide study showed a hypokinetic apex and an ejection fraction of 60 per cent. She remained asymptomatic in the interim and throughout pregnancy on the following medications: propranolol (for prevention of myocardial ischaemia), cholestyramine (for reduction of serum cholesterol levels) and haloperidol (for control of her psychiatric disorder). However, she persisted in smoking heavily. An echocardiogram performed during the second trimester was interpreted as normal. The current acute exacerbation of paranoia responded to increased doses of haloperidol and psycho-supportive measures but the patient remaincd anxious about the outcome of pregnancy and was therefore scheduled for elective induction of labour. Physical examination was unremarkable; haematologic variables and serum electrolytes were within normal limits, and an ECG showed regular sinus rhythm without ST-T wave changes.

On the evening before induction, a thorough and reassuring preanaesthetic visit succeeded in alleviating the patient's apprehension. Early the next morning, after intake of her usual medications, a central venous catheter was placed via the right basilic vcin; position of the tip in the superior vena cava was confirmed by chest radiogram. A peripheral intravenous line was used for hydration and oxytocin infusion. Oxygen was administered by nasal cannulae $\left(4 \mathrm{~L} \cdot \mathrm{min}^{-1}\right)$. A five-lead ECG and blood oxygen saturation by pulse oximeter were monitored throughout and arterial blood pressure (BP) was recorded by automated cuff at frequent intervals. After central venous pressure (CVP) had been increased from $0.3 \mathrm{kPa}(3 \mathrm{~cm}$ $\left.\mathrm{H}_{2} \mathrm{O}\right)$ to $0.5 \mathrm{kPa}\left(5 \mathrm{~cm} \mathrm{H}_{2} \mathrm{O}\right)$ by infusion of lactated Ringer's solution with five per cent dextrose, an extradural catheter was inserted at the $\mathbf{L}_{3-4}$ interspace with the patient in the right lateral position. A total of $7 \mathrm{ml}$ of two per cent 2-chloroprocaine was injected, $3 \mathrm{ml}$ as test-dose and $4 \mathrm{ml}$ after the patient had turned to the left lateral 
posture. Analgesia was satisfactory (sensory leve] $\mathrm{T}_{4}$ through $\mathrm{L}_{1}$ ), heart rate remained stable and bload pressure (BP) declined from $18 / 11 \mathrm{kPa}(135 / 80 \mathrm{mmHg})$ to $17 / 11$ $\mathrm{kPa}(128 / 80 \mathrm{mmHg})$. Thirty-five minutes later, the patient began to experience low back and symphyseal discomfort during contractions. The extradural block was reinforced with two 4-ml increments of a mixture of 0.20 per cent bupivacaine with fentanyl $10 \mu \mathrm{g} \cdot \mathrm{ml}^{-1 *}$ which provided pain relief for the following $2 \frac{1}{2}$ hours. A lateral posture was maintained at all times. Twenty minutes after full dilation of the cervix, the patient was taken to the delivery room where a perineal dose of $10 \mathrm{ml}$ of three per cent 2-chloroprocaine was injected in the semi-sitting position. After a median episiotomy was performed, a vigorous baby (Apgar scores 8 and 9, respectively) was delivered with the aid of low forceps. The mother experienced no discomfort; BP was $13 / 11 \mathrm{kPa}$ (100/80 $\mathrm{mmHg}$ ), heart rate 90 beats' $\mathrm{min}^{-1}$ and CVP $0.8 \mathrm{kPa}(8 \mathrm{~cm}$ $\mathrm{H}_{2} \mathrm{O}$ ). Only six hours later did the patient complain of mild lower abdominal pain. Both mother and newborn were discharged in good condition on the third postpartum day

\section{Discussion}

Surgical patients who had undergone coronary revascularization following a myocardial infarct were reported to represent a lower operative risk than similar patients who had not received a bypass graft. ${ }^{2}$ Although our parturient had had revascularization and was free of angina, her abnormal myocardial wall function, genetic disease and smoking habit placed her at an increased risk for myocardial ischaemia. Furthermore, in patients subjected to non-cardiac surgery subsequent to coronary artery bypass grafting, hypotension represented a major risk factor for intraoperative myocardial ischaemia, particularly when associatcd with tachycardia. ${ }^{3}$ Our goal of management was directed therefore toward prevention of haemodynamic instability during labour and parturition by alleviation of pain and stress with avoidance of anaesthesiarelated complications. This aim was achieved by the following measures: (1) administration of the usual propranolol dosage; (2) increase in inhaled oxygen concentration; (3) avoidance of aortocaval compression; (4) early institution of segmental lumbar extradural analgesia with slow advancement of the block; (5) monitoring of ECG and of arterial pressure and oxygenation by non-invasive means; and (6) monitoring of intravascular fluid status by the method of lowest morbidity, i.e., peripherally placed central venous catheter. Since left ventricular function was not significantly diminished,

*Mixture of 0.25 per cent bupivicaine $8 \mathrm{ml}$ and fentanyl $2 \mathrm{ml}$ inscrtion of a pulmonary artery catheter was deemed unnecessary.

Maintenance of the usual propranolol medication is necessary to prevent myocardial ischaemia caused by a rebound increase in beta-adrenergic receptor stimulation. Supplemental oxygen is indicated because the physiologic demands of labour may exceed the patient's limited cardiac reserves. Lumbar extradural analgesia is the method of choice for labour and vaginal delivery, ${ }^{4}$ as it produces complete pain relief and alleviates the cardiovascular, respiratory, metabolic and hormonal stress responses to uterine contractions. It allows for separate blockade of the spinal segments involved in the first stage of labour $\left(\mathrm{T}_{10}-\mathrm{L}_{1}\right)$ and those of the second stage $\left(\mathrm{S}_{2}-\mathrm{S}_{4}\right)$ thereby reducing the total dose of local anaesthetic as well as the extent of sympathetic and motor blockade so that arterial hypotension is minimized and premature relaxation of the pelvic floor is avoided. The risk of hypotension can be reduced by slow advancement of the level of blockade (to facilitate compensation to the sympathetic blockade), by prevention of aortocaval compression (to maintain venous return to the heart): by appropriate intravenous hydration (aided by CVP mcasurements) and by the anaesthetic technique employed. Prevention of hypotension is of utmost importance in a parturient on propranolol therapy because ephedrine, the recommended vasopressor in pregnancy, may be less effective due to blockade of the beta-adrenergic receptors in the heart.

Chloroprocaine was chosen for the initial injection because of its rapid onset and short duration of action. However, a bupivacaine-fentanyl combination was preferred for maintenance as narcotics provide pain relief for the first stage of labour without affecting the sympathetic nervous system so that the risk of arterial hypotension is reduced. Bupivacaine was selected for combination with fentaryl because of the effectiveness of this mixture ${ }^{5}$ and its lack of adverse fetal/neonatal effects ${ }^{6}$ Chloroprocaine. was used for the second stage of labour to prevent prolonged perineal paralysis and inus facilitate early spontancous voiding. ${ }^{7}$

As more and more women postpone pregnancy until their thirties or even later ${ }^{8}$ and as ischaemic heart disease strikes women at an earlier age than in the past, ${ }^{9.10}$ an increasing number of parturients suffering from ischaemic heart disease will require anaesthetic care for labour and vaginal delivery. Particular attention should be paid to maintaining the balance berween myocardial oxygen demand and supply utilizing the following measures: continuation of the daily cardiac medications, inhalation of supplemental oxygen, early institution of lumbar extradural block and avoidance of substantial falls in arterial pressure or increases in heart rate. 


\section{References}

1 Ginz $B$. Myocardial infarction in pregnancy. J Obstet Gynaecol Br Commonw 1970; 77: 610-5.

2 Mahar $L$. Steen PA, Tinker JH, Vliestra RE. Smith HC Pluth $J R$. Perioperative infarction in patients with coronary artery disease with and without aorto-caval bypass grafts. J Thorac Cardiovasc Surg 1978; 76: 533-7.

3 Backofen JE, Schauble JF, Baughman $K L$. Does prior coronary revascularization protect from ischemia during noncardiac surgery? Anesthesiology 1984; 6l: A92.

4 Chestmut $D H$, Vatnik FJ, Pitkin RM, Varner $M W$. Prcgnancy in a patient with a history of myocardial infarction and coronary artery bypass grafting. Am J Obstet Gynecol 1986; 155: 372-3

5 Justirs DM. Francis D, Houltan PG, Reynolds F. A controlled trial of extradural fentanyl in labour. $\mathrm{Br} \mathrm{J}$ Anacsth 1982; 54: 409-14.

6 Cohen SE, Tan S, Albright GA, Halpern I. Epidural fentanyl/bupivacaine mixtures for obstetric analgesia. Anesthesiology 1987: 67: 403-4.

7 Bridenbaugh $L D$. Cathetcrization after long- and shortacting local anesthctics for continuous caudal block for vaginal delivery. Ancsthcsiology 1977; 46: 357-9.

8 Brooks $G Z$. Aneschesia for the Critical-Care Obstetric Patient. Chapter 5. In: Berkowitz RL (Ed). Critical Care of the Obstetric Patient, New York, Churchil] Livingstone, 1983, p 119.

9 Parrish HM, Carr CA, Silberg SL, Goldner JC. Increasing autopsy incidence of coronary heart disease in women, Arch Intern Med 1966; 118; 436-45.

10 Oliver $M F$. Ischaemic heart disease in young women. $\mathrm{Br}$ Med J 1974: 4: 253-9.

\section{Résumé}

Un nombre croissant de femmes enceintes souffrant de maladie cardiaque ischémique requièrent des soins anesthésiques pour le travail et l' accouchement. On présente le cas d' une femme de 42 ans ayant souffert d'un infarctus du myocarde nécessitam un pontage aorocoronarien. La conduite anesthésique a ésé orientée vers la prévention de l'instabilité hémodynamique par l'abolition de la douleur et du stress et en réduisan les risques des complications anesthésiques. Le monitorage comprenait un cathéter veineux central, un saturomètre et un sphygmomanomètre automatisé. Une ancsthésie lombaire péridurate segmentaire avait âté faite au préalable avec un anesthésique local additionné de fentanyl. 